\title{
Chikungunya Virus Detection in Aedes aegypti and Culex quinquefasciatus during an Outbreak in the Amazon Region
}

\author{
Ana Cecília Ribeiro Cruz ${ }^{1,2}{ }^{\mathbb{D}}$, Joaquim Pinto Nunes Neto ${ }^{1, *}$, Sandro Patroca da Silva ${ }^{1}$, \\ Eliana Vieira Pinto da Silva ${ }^{1}$, Glennda Juscely Galvão Pereira ${ }^{1,3}$, Maissa Maia Santos ${ }^{1}$, \\ Hamilton Antônio de Oliveira Monteiro ${ }^{1}$, Flavia Barreto dos Santos ${ }^{4}$, \\ Ricardo José de Paula Souza e Guimarães ${ }^{1}$, Carine Fortes Aragão ${ }^{1,3}$ (D) and Lívia Carício Martins ${ }^{1}$ \\ 1 Seção de Arbovirologia e Febres Hemorrágicas, Instituto Evandro Chagas, Secretaria de Vigilância e Saúde, \\ Ministério da Saúde, Ananindeua, PA 67030-000, Brazil; anacecilia@iec.gov.br (A.C.R.C.); \\ spatroca@gmail.com (S.P.d.S.); elianapinto@iec.gov.br (E.V.P.d.S.); bioagl2013@gmail.com (G.J.G.P.); \\ maissasantos@iec.gov.br (M.M.S.); hamiltonmonteiro@iec.gov.br (H.A.d.O.M.); \\ ricardoguimaraes@iec.gov.br (R.J.d.P.S.eG.); carinefaragao@gmail.com (C.F.A.); liviamartins@iec.gov.br (L.C.M.) \\ Departamento de Patologia, Universidade do Estado do Pará, Belém, PA 66087-662, Brazil \\ Programa de Pós-Graduação em Virologia, Instituto Evandro Chagas, Ananindeua, PA 67030-000, Brazil \\ 4 Laboratório de Imunologia Viral, Fundação do Instituto Oswaldo Cruz, Rio de Janeiro, RJ 21040-900, Brazil; \\ flaviab@ioc.fiocruz.br \\ * Correspondence: joaquimneto@iec.gov.br; Tel.: +55-91-32142284
}

Received: 30 May 2020; Accepted: 3 July 2020; Published: 4 August 2020

\begin{abstract}
Chikungunya virus (CHIKV) was first reported in Brazil in 2014 and, after it spread countrywide, an outbreak of febrile illness with reports of arthralgia happened in the municipality of Xinguara, Pará, Brazil in 2017, indicating the virus' circulation. Here, we aimed to investigate CHIKV in mosquito vectors collected during an active surveillance of virus isolation in cell culture by using molecular detection and viral genome sequencing. A total of 492 Aedes, Culex and Mansonia mosquitoes were collected and separated in 36 pools according to the species and sex, and $22.2 \%$ (8/36) were positive. CHIKV was indentified in pools of Ae. aegypti females $(n=5)$, an Ae. aegypti male $(n=1)$ and in Culex quinquefasciatus females $(n=2)$. However, as the mosquitoes' whole bodies were macerated and used for detection, one cannot suggest the role of the latter in the viral transmission. Despite this, vector competence studies must be carried out in the different species to investigate long-term adaptations. Viral genome sequencing has characterized the East-Central-South-African (ECSA) genotype in all positive pools analyzed, corroborating previous reports for the Amazon region.
\end{abstract}

Keywords: Chikungunya; Aedes aegypti; Culex quinquefasciatus; East-Central-South-Africa genotype; entomological surveillance; Amazon; Brazil

\section{Introduction}

Chikungunya virus (CHIKV) is a single-strand RNA virus belonging to the Togaviridae family, of the Alphavirus genus, transmitted by mosquitoes and often causing an acute febrile illness accompanied by severe and debilitating arthralgia in human-chikungunya fever [1]. CHIKV caused massive and sustained outbreaks in Asia and Africa between the 1960s and 1980s. After this period, there was a decrease in the number of cases, until 2004, when an epidemic was reported in Kenya, Africa, resulting in the occurrence of outbreaks in both the aforementioned continents $[2,3]$. In the Americas, only imported cases from endemic Asian and African areas were reported for almost a decade [3], however, in 2013, the first autochthonous cases were confirmed in the Caribbean islands [4]. In the 
following year, Brazil confirmed the first autochthonous cases in Oiapoque, state of Amapá, the North region, and Feira de Santana, of Bahia, the Northeast region [5] and soon, the virus spread nationwide in the following years, resulting in epidemics in 2016 and 2017 [6,7].

Phylogenetic studies revealed the worldwide circulation of four CHIKV genotypes, the names of which were based on their geographical distribution: (I) West Africa, (II) East-Central-South Africa (ECSA), (III) Asia and (IV) Indian Ocean (IOL) [8]. The Asian genotype was responsible for the first cases of chikungunya in the Americas [2] and, in Brazil, it was introduced in the state of Amapá, while, in Bahia, the first infections were caused by the ECSA genotype [9]. Currently, the two genotypes remain co-circulating in the country and are the only ones reported so far.

The rapid spread and establishment of CHIKV in Brazil was facilitated by the high density of its main vector-Aedes (Ae.) aegypti, a species of great importance in the viral transmission dynamics of the country [10]. Moreover, the favorable climate, associated with the disordered urbanization and wide availability of reservoirs serving as breeding sites, favored the proliferation of these vectors and, consequently, increased the viral transmission [11-13]. Therefore, mosquito control is still the main strategy to prevent epidemics. The lack of a specific treatment and vaccine reinforces the importance of vector control [14]. After zika emergence, vector control strategies were intensified, but were not enough to avoid the increased number of Ae. aegypti-related diseases [15].

According to the Brazilian Ministry of Health (MoH), in 2016 and 2017 a total of 271,824 and 185,593 cases of chikungunya were confirmed in Brazil, with 196 and 173 deaths, respectively [6,7]. In the North region, the state of Pará had the highest number of notifications, reporting 48.2\% (4343/9019) and 51.3\% (8505/16,570) of the cases from the North region, respectively [7]. In 2017, the municipality of Xinguara, Pará, reported an outbreak of febrile illness associated with severe arthralgia, suggesting the occurrence of chikungunya infections. Therefore, we aimed to investigate the CHIKV infection in mosquitoes collected in the urban areas of Xinguara, located in the Amazon region of Brazil.

\section{Materials and Methods}

\subsection{Study Area}

This study was carried out in the municipality of Xinguara, located in the Southeast Mesoregion of the state of Pará, North Brazil (Figure 1). The municipality has 40,573 inhabitants and an area of $3779.348 \mathrm{~km}^{2}$, is located in the Amazon and, therefore, suffers the environmental influences typical of the region [16]. The vegetation is represented by the equatorial latifoliated forest, presenting areas of mixed and cerrado forest. The relative humidity is high (an average of $78 \%$ ), ranging from $90 \%$ in the rainy season (November to May) to 52\% in the dry season (June to October), and an average annual temperature of $26.35^{\circ} \mathrm{C}$ and a rainfall of around $2000 \mathrm{~mm}$ [17].

\subsection{Mosquitoes Collection and Identification}

The mosquitoes were collected by a team from the Arbovirology and Hemorrhagic Fevers Section (SAARB) of the Medical Entomology Laboratory and the Evandro Chagas Institute (IEC), as requested by the MoH to investigate suspected chikungunya cases in Xinguara in January of 2017. The active surveillance was performed using a puçá and consisted of capturing the mosquitoes in flight, which were then retained in a fabric net. The collection was performed inside residences located in: the Centro, Itamarati, Tanaka II and Novo Horizonte neighborhoods; inside and outside residences in the Frei Henry neighborhood, and near the building of an Emergency Care Unit (ECU), located in the Centro neighborhood (Figure 1). The collected mosquitoes were immediately transferred, with the aid of an oral suction device, to tubes with the appropriate date and place of collection, stored in liquid nitrogen at $-196^{\circ} \mathrm{C}$ and sent to the IEC for species identification using dichotomous keys [18-24] in a refrigerated table at $-20^{\circ} \mathrm{C}$. Once identified, the mosquitoes were quantified and grouped in pools, according to species, sex and place of collection. The pools were identified with an exclusive registration, adopted by SAARB/IEC, composed by the acronym AR (of ARtropod) followed by a sequential number. 


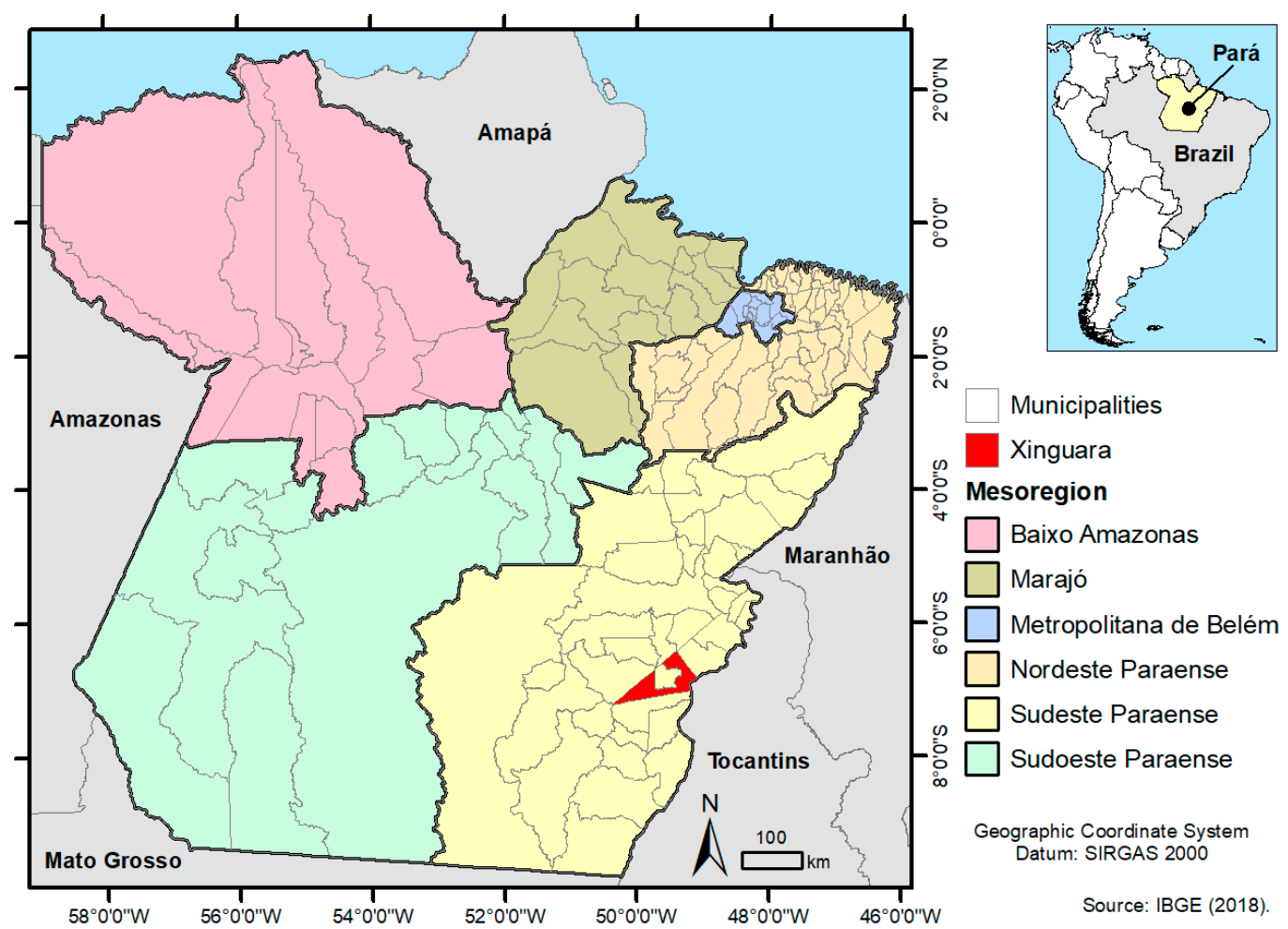

Figure 1. Study area. Municipality of Xinguara, located in the Southeast Mesoregion of the state of Pará, North Brazil.

\subsection{Mosquitoes Preparation}

The mosquitoes' suspensions were obtained by macerating each pool in $1 \mathrm{~mL}$ of a solution composed of Dulbecco's Phosphate Buffered Saline 1X (D-PBS (Life technologies, Carlsbad, CA, USA)), 2\% penicillin and streptomycin, $1 \%$ fungizone and $5 \%$ fetal bovine serum (FBS). Macerates were obtained using a TissueLyser II (Qiagen, Hilden, Germany) at a frequency of $25 \mathrm{~Hz}$ for $1 \mathrm{~min}$, and with the aid of a $3 \mathrm{~mm}$ tungsten sphere, based on an adapted protocol [25]. The macerates were kept at $-70{ }^{\circ} \mathrm{C}$ for $12 \mathrm{~h}$.

\subsection{Virus Isolation}

As the gold standard test for investigating arboviruses, the mosquitoes' macerates were submitted to virus isolation using Aedes albopictus C6/36 clone (ATCC: CRL1 660) cells seeded in $10 \mathrm{~mL}$ culture tubes containing $1.5 \mathrm{~mL}$ of glutamine-modified Leibowitz medium (L-15), with $2.95 \%$ tryptose phosphate, non-essential amino acids and antibiotics (penicillin and streptomycin), and $2 \%$ fetal bovine serum, for a period of three days. Prior to inoculation, the mosquito pools' macerates were centrifuged for $10 \mathrm{~min}$, at $10,000 \times \mathrm{g} \mathrm{rpm}$, at $4{ }^{\circ} \mathrm{C}$. The cell culture medium was discarded and $100 \mu \mathrm{L}$ of the sample supernatant was inoculated into the cell monolayers and incubated at $28{ }^{\circ} \mathrm{C}$ for one hour for adsorption, with stirring performed every $15 \mathrm{~min}$. Inoculated cells were kept in the $1.5 \mathrm{~mL} \mathrm{L-15}$ medium, with $2.95 \%$ tryptose phosphate, non-essential amino acids, antibiotics (penicillin and streptomycin) and $2 \%$ FBS, according to an adapted protocol [26]. Inoculated cells were kept at $28^{\circ} \mathrm{C}$ and were observed daily for a period of 7 days or until the presence of a cytopathic effect (CPE).

\subsection{Indirect Immunofluorescence Test}

Virus identification was performed by using immunofluorescence, as previously described [27], with modifications. Briefly, the inoculated cells were harvested, fixed for ten minutes in acetone and kept at $-20^{\circ} \mathrm{C}$. Subsequently, $10 \mu \mathrm{L}$ of polyclonal antibodies was added to arboviruses of the Alphavirus, Flavivirus, Orthobunyavirus and Phlebovirus genuses, diluted to 1:20 in PBS with a pH of 7.4 and incubated for $30 \mathrm{~min}$. After an incubation at $37^{\circ} \mathrm{C}$, with $5 \% \mathrm{CO}_{2}$, cells were washed three 
times in PBS with a $\mathrm{pH}$ of 7.4 and were given a quick wash in distilled water. After air drying, $10 \mu \mathrm{L}$ of anti-mouse conjugate (Cappel) diluted to 1:900 was added and the slides were incubated for $30 \mathrm{~min}$. Next, slides were analyzed in a fluorescence microscope (Olympus BX51, UPlanFL N 20X/0.5 objective and WB and U-25nd filters, Olympus, Tokyo, Japan). Positive samples, identified by their immunofluorescence, were further tested by the RT-qPCR for confirmation and subsequent nucleotide sequencing.

\subsection{Viral RNA Extraction and Real-Time Reverse Transcriptase Polymerase Chain Reaction (RT-qPCR)}

Viral RNA extraction was performed using the QIAamp ${ }^{\circledR}$ viral RNA kit (Qiagen, Hilden, Germany), according to the manufacturer's instructions. A non-competitive internal control (genomic phage RNA MS2, Roche Diagnostics, Basel, Switzerland) [28] was used as positive control and as a negative control, the latter of which consisted of nuclease-free water. The RT-qPCR assay was performed using the SuperScript ${ }^{\circledR}$ III Platinum ${ }^{\circledR}$ One-Step RT-qPCR Kit (ThermoFisher Scientific, Waltham, MA, USA), which contains the specific primers and probe for detecting the CHIKV NSP1 protein [29]. Briefly, the $25 \mu \mathrm{L}$ reaction consisted of $12.5 \mu \mathrm{L}$ of reaction mix ( $2 \times$ concentrated), $5.5 \mu \mathrm{L}$ of nuclease-free water, $1.0 \mu \mathrm{L}$ of Forward and Reverse primer, $0.5 \mu \mathrm{L}$ of probe, $0.5 \mu \mathrm{L}$ of the Super Script III platinum Taq Mix enzyme and $5 \mu \mathrm{L}$ of the extracted RNA, and was performed on the 7500 Fast Real-Time PCR system (ThermoFisher Scientific, Waltham, MA, USA). The cycling conditions consisted of an initial RT step at $50{ }^{\circ} \mathrm{C}$ for $30 \mathrm{~min}$, followed by a 2 min denaturation step at $95^{\circ} \mathrm{C}$, and then 45 cycles of $15 \mathrm{~s}$ at $95^{\circ} \mathrm{C}$ and $1 \mathrm{~min}$ at $60^{\circ} \mathrm{C}$. Positive (CHIKV infected mouse brain) and negative (nuclease-free water) controls were included. The samples were analyzed in duplicate and considered as positive when the average cycle threshold $(\mathrm{Ct})$ value was less than 37 .

\subsection{Genome Sequencing and Phylogenetic Analysis}

The viral genome was recovered by synthesizing the first and second complementary DNA (cDNA) strands, constructed directly from the single-stranded RNA (ssRNA). Briefly, the synthesis was performed using the cDNA Synthesis System kit (Roche Diagnostics, Basel, Switzerland) and $400 \mu \mathrm{M}$ of Roche random primer. The products were purified using magnetic beads (Agencourt AMPure XP Reagent, Beckman Coulter, CA, USA) and were given three washes with $800 \mu \mathrm{L}$ of $70 \%$ ethanol. The cDNA was eluted in $16 \mu \mathrm{L}$ of $10 \mathrm{mM}$ of Tris- $\mathrm{HCl}$ (pH 7.5). The cDNA library was prepared and sequenced using the protocol described in the Nextera XT DNA Library Preparation Kit on a MiniSeq platform (Illumina Inc., San Diego, CA, USA).

The genome assembly was carried out using the De Novo Assembler methodology in the IDBA-UD program [30]. All the contigs were aligned and compared to the virus protein (RefSeq) database available in National Center for Biotechnology Information (NCBI) through DIAMOND [31]. The result was visualized using Megan6 software [32] and the inspection and annotations of putative open reading frame (ORF) genes were performed using Geneious v. 9.1.6 software (Biomatters, Auckland, New Zealand).

A multiple sequence alignment (MSA) was performed using the Mat v. 7 program [33]. Before phylogenetic analysis, the ProtTest was applied to select the best-fit models of amino acid substitution [34]. The reconstruction of phylogenetic trees was performed using the maximum likelihood (ML) method [35] implemented in RaxML v. 8.2.4 [36]. To determine the reliability of the tree topology, a bootstrap analysis [37] was carried out on 1000 replicates.

\section{Results}

\subsection{Collection and Identification}

A total of 492 mosquitoes were collected and 36 pools were formed. $C x$. quinquefasciatus $(68.7 \%$, $47.6 \%$ females and $21.1 \%$ males) and Ae. aegypti (28.6\%, 21.3\% females and $7.3 \%$ males) were the predominant species collected. Ae. albopictus specimens were collected in the Centro and Frei Henry neighborhoods. One Ae. scapularis female and one Ae. serratus female were also collected in Centro. 
Among the collection sites, the largest number of specimens $(55.1 \%$; 319/492) were collected in the Centro neighborhood, where most Ae. aegypti and $C x$. quinquefasciatus specimens, as well as the only Mansonia (Mansonia) specie were collected (Table 1).

Table 1. Distribution of mosquitoes according to species, sex and the collection site in Xinguara, Pará during an outbreak of chikungunya, 2017.

\begin{tabular}{|c|c|c|c|c|c|c|c|c|c|c|c|c|c|}
\hline \multirow{3}{*}{ Species (oor $\sigma^{x}$ ) } & \multicolumn{10}{|c|}{ Collection Sites } & \multicolumn{3}{|c|}{ Total } \\
\hline & \multicolumn{2}{|c|}{ Centro } & \multicolumn{2}{|c|}{ Itamarati } & \multicolumn{2}{|c|}{$\begin{array}{c}\text { Tanaka } \\
\text { II }\end{array}$} & \multicolumn{2}{|c|}{$\begin{array}{c}\text { Frei } \\
\text { Henry }\end{array}$} & \multicolumn{2}{|c|}{$\begin{array}{c}\text { Novo } \\
\text { Horizonte }\end{array}$} & \multirow[b]{2}{*}{$\mathbf{N}$} & \multirow[b]{2}{*}{$\mathbf{P}$} & \multirow[b]{2}{*}{$\%$} \\
\hline & $\mathbf{N}^{1}$ & $\mathbf{P}^{2}$ & $\mathbf{N}$ & $\mathbf{P}$ & $\mathbf{N}$ & $\mathbf{P}$ & $\mathbf{N}$ & $\mathbf{P}$ & $\mathbf{N}$ & $\mathbf{P}$ & & & \\
\hline Ae. aegypti우 & 84 & 5 & 5 & 1 & 4 & 1 & 5 & 1 & 7 & 1 & 105 & 9 & 21.3 \\
\hline Ae. aegypti $\sigma^{7}$ & 28 & 2 & 3 & 1 & 4 & 1 & 0 & 0 & 1 & 1 & 36 & 5 & 7.3 \\
\hline Ae. albopictus ㅇ & 2 & 1 & 0 & 0 & 0 & 0 & 5 & 1 & 0 & 0 & 7 & 2 & 1.4 \\
\hline Ae. albopictus $\sigma^{\top}$ & 0 & 0 & 0 & 0 & 0 & 0 & 3 & 1 & 0 & 0 & 3 & 1 & 0.6 \\
\hline Ae. scapularis + & 1 & 1 & 0 & 0 & 0 & 0 & 0 & 0 & 0 & 0 & 1 & 1 & 0.2 \\
\hline Ae. serratus 우 & 1 & 1 & 0 & 0 & 0 & 0 & 0 & 0 & 0 & 0 & 1 & 1 & 0.2 \\
\hline Cx. quinquefasciatus + & 152 & 6 & 11 & 1 & 34 & 1 & 29 & 1 & 8 & 1 & 234 & 10 & 47.6 \\
\hline Cx. quinquefasciatus $\sigma^{7}$ & 50 & 2 & 6 & 1 & 36 & 1 & 10 & 1 & 2 & 1 & 104 & 6 & 21.1 \\
\hline Mansonia (Mansonia) sp. ${ }^{3}$ q & 1 & 1 & 0 & 0 & 0 & 0 & 0 & 0 & 0 & 0 & 1 & 1 & 0.2 \\
\hline Total & 319 & 19 & 25 & 4 & 78 & 4 & 52 & 5 & 18 & 4 & 492 & 36 & 100 \\
\hline
\end{tabular}

\subsection{Virus Isolation and Molecular Detection}

All pools were submitted to virus isolation and 22.2\% (8/36) were positive. CHIKV was isolated in pools of Ae. aegypti females $(n=5)$, Ae. aegypti male $(n=1)$ and in $C x$. quinquefasciatus females $(n=2)$. After RT-qPCR, a CHIKV infection was confirmed in seven pools, as one pool was no longer available after virus isolation for molecular detection. RT-qPCR Ct values observed on the CHIKV positive pools of Ae. aegypti females ranged from 20.2 to 23.3, and after isolation in cell culture, $\mathrm{Ct}$ values ranged from 12.1 to 13.9. The two CHIKV positive pools of $C x$. quinquefasciatus females presented $C t$ values of 28.2 and 33.7, and after isolation in cell culture, those were 13.4 and 18.9, respectively (Table 2).

Table 2. Investigation of mosquito pools by virus isolation and RT-qPCR during the chikungunya outbreak in Xinguara, Pará, 2017.

\begin{tabular}{|c|c|c|c|c|c|c|c|c|c|}
\hline \multirow[b]{2}{*}{$\begin{array}{l}\text { Pool } \\
\text { Number }\end{array}$} & \multirow[b]{2}{*}{ N. ${ }^{1}$} & \multirow[b]{2}{*}{ Species $\left(+\right.$ or $\left.\sigma^{7}\right)$} & \multirow[b]{2}{*}{$\begin{array}{l}\text { Collection } \\
\text { Date }\end{array}$} & \multirow[b]{2}{*}{$\begin{array}{l}\text { Collection } \\
\text { Site }\end{array}$} & \multirow[b]{2}{*}{$\begin{array}{c}\text { Virus } \\
\text { Isolation }\end{array}$} & \multicolumn{4}{|c|}{ RT-qPCR } \\
\hline & & & & & & Pool & $\mathrm{Ct}^{2}$ & $\begin{array}{c}\text { Cell } \\
\text { Supernatant }\end{array}$ & $\mathrm{Ct}^{2}$ \\
\hline AR843521 & 15 & $\begin{array}{c}\text { Ae. Aegypti } \\
+\end{array}$ & $\begin{array}{l}24 \text { January } \\
2017\end{array}$ & Centro & $\mathrm{CHIKV}^{3}$ & CHIKV & 21.3 & CHIKV & 13.9 \\
\hline AR843522 & 21 & $\begin{array}{c}\text { Ae. aegypti } \\
+ \\
+\end{array}$ & $\begin{array}{l}25 \text { January } \\
2017\end{array}$ & Centro & CHIKV & CHIKV & 21.3 & CHIKV & 12.1 \\
\hline AR843523 & 21 & $\begin{array}{c}\text { Ae. aegypti } \\
\circ\end{array}$ & $\begin{array}{l}25 \text { January } \\
2017\end{array}$ & Centro & CHIKV & CHIKV & 23.3 & CHIKV & 13 \\
\hline AR843524 & 23 & $\begin{array}{c}\text { Ae. aegypti } \\
+ \\
\end{array}$ & $\begin{array}{l}\text { 26 January } \\
2017 \\
\end{array}$ & Centro & CHIKV & CHIKV & 21 & CHIKV & 13.9 \\
\hline AR843525 & 26 & $\begin{array}{c}\text { Ae. aegypti } \\
\sigma^{2}\end{array}$ & $\begin{array}{l}24 \text { January } \\
25\end{array}$ & Centro & CHIKV & $\mathrm{ND}^{4}$ & - & $\mathrm{ND}^{4}$ & - \\
\hline AR843528 & 35 & $\begin{array}{c}C x . \\
\text { quinquefasciatus } \\
q\end{array}$ & $\begin{array}{l}25 \text { January } \\
2017\end{array}$ & Centro & CHIKV & CHIKV & 28.2 & CHIKV & 13.4 \\
\hline AR843529 & 27 & $\begin{array}{c}C x . \\
\text { quinquefasciatus } \\
\wp\end{array}$ & $\begin{array}{l}26 \text { January } \\
2017\end{array}$ & Centro & CHIKV & CHIKV & 33.7 & CHIKV & 18.9 \\
\hline AR843544 & 4 & $\begin{array}{c}\text { Ae. aegypti } \\
\wp\end{array}$ & $\begin{array}{l}25 \text { January } \\
\text { and }\end{array}$ & Tanaka II & CHIKV & CHIKV & 20.2 & CHIKV & 12.5 \\
\hline
\end{tabular}

\footnotetext{
${ }^{1}$ Number of mosquitoes collected; ${ }^{2}$ Cycle threshold value; ${ }^{3}$ Chikungunya virus; ${ }^{4}$ Not done; : Female; $0^{\text {: }}$ : Male.
} 


\subsection{Phylogenetic Analysis}

The CHIKV positive pools AR843521 (GenBank access number MT526900) and AR843523 (access number MT526901) are representative of Ae. aegypti females; AR843528 (access number MT526902) and AR843529 (access number MT526903) are representative of the $C x$. quinquefasciatus females, all collected on the Centro site; AR843544 (access number MT526904) is representative of the Ae. aegypti females collected on the Tanaka II site, were all selected for viral genome sequencing. Phylogeny based on the complete genome analysis characterized the CHIKV, in all the pools analyzed, as belonging to the ECSA genotype (Figure 2), with a high similarity to other samples previously detected in North and Northeast Brazil.

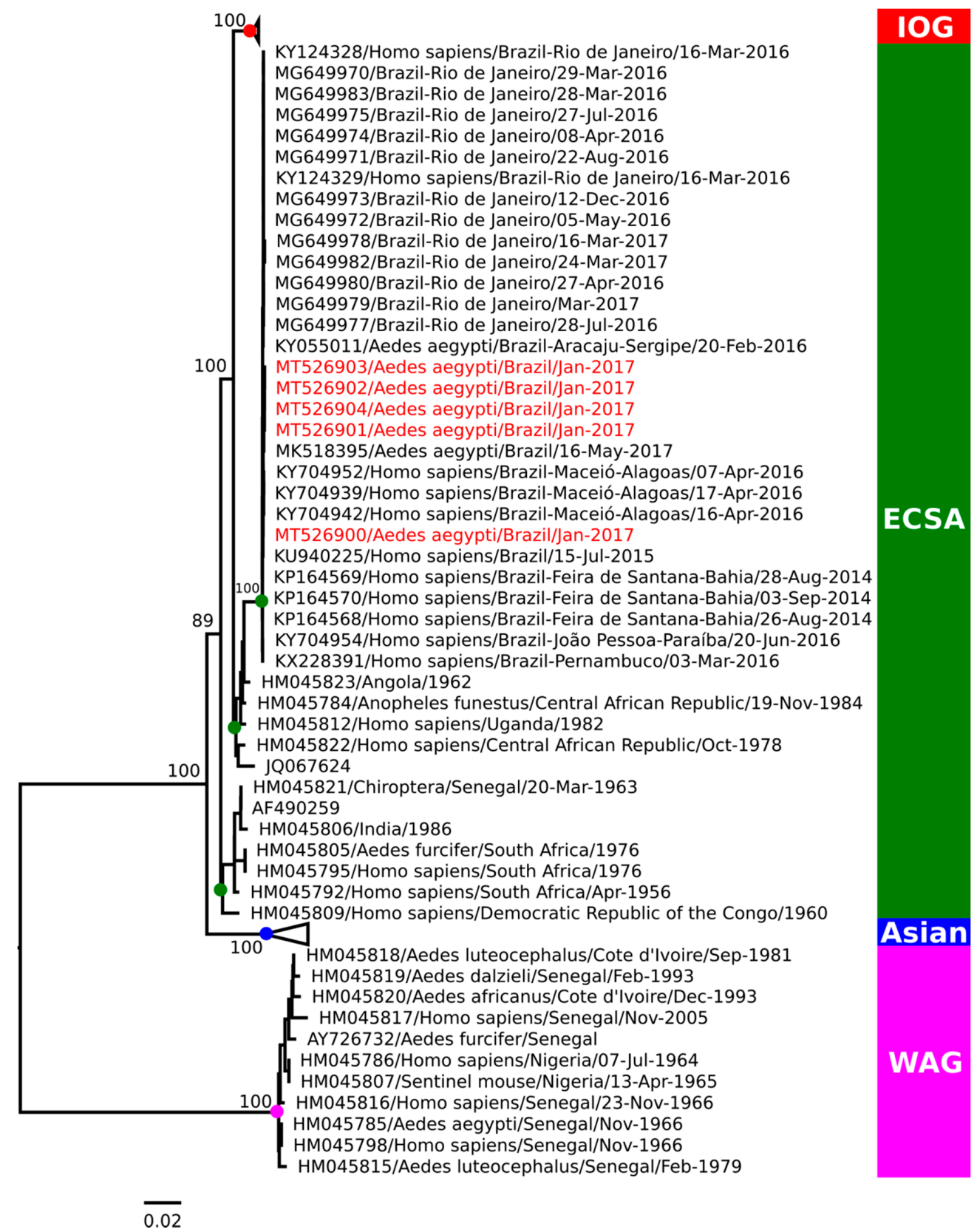

Figure 2. Maximum likelihood phylogenetic analysis based on the complete genome of chikungunya virus (CHIKV) isolated in females of Ae. aegypti and $C x$. quinquefasciatus, collected during an outbreak in the Amazon region in 2017. The strains sequenced in this study are in red. Colored circles-red, green, blue and magenta - on the tree nodes represent the Indian Ocean, ECSA, Asian and West Africa clusters, respectively. 


\section{Discussion}

In the present study, we identified CHIKV in Ae. aegypti (males and females) and Cx. quinquefasciatus (females), confirming that virus circulation took place during an outbreak in the municipality of Xinguara, Pará in 2017. Ae. aegypti mosquitoes are a worldwide recognized vector for CHIKV and, in Brazil, female mosquitoes of the same species have already been found naturally infected in the states of Sergipe [38] and Maranhão [39,40], both in the Northeast region of the country. A recent study in an urban park in Rio Grande do Norte, also in the Northeast, identified CHIKV in pools of Ae. aegypti females, Ae. albopictus females and males, in Ae. fluviatilis and in Wyeomyia bourrouli [41]. However, this is the first report of an Ae. aegypti male naturally infected by CHIKV in the country, which implies transovarian transmission. Populations of Ae. aegypti males collected in Mexico [42] and Thailand [43] have also been identified to be naturally infected with CHIKV. It has been shown that the high vector competence of both Ae. aegypti and Ae. albopictus in transmitting CHIKV plays an important role in the virus spread in American countries [44].

We also reported the natural infection of $C x$. quinquefasciatus, however, one can not speculate and imply that the species is participating in the CHIKV transmission. One limitation of this study is that the mosquitoes had their bodies macerated and analyzed as a whole, and salivary gland analysis, that could be indicative of vector competence, was not performed.

Most mosquito pools that tested positive for CHIKV were collected in the Centro neighborhood near an ECU, which is of particular concern, as it constitutes a highly busy area, with an intense population movement seeking medical assistance and which may have favored the virus dissemination. Therefore, it is suggested that vector control measures shall be intensified in such areas.

In this study, phylogeny characterized the CHIKV ECSA genotype in all the pools analyzed. The sequence recovered from the sample AR843521 was closely related to those previously collected from Bahia in 2015 (GeneBank accession number KU940225) [45] and Alagoas in 2016 (KY704942) [46], while the others (AR843523, AR843528, AR843529 and AR843544), were more related to viruses identified in Ae. aegypti collected in Sergipe in 2016 (KY055011) [38] and Maranhão in 2017 (MK518395) [40]. The same genotype has already been reported during an outbreak in the state of Roraima [47], also in the North region of Brazil, demonstrating this genotype's dissemination and persistence in the region.

The CHIKV ECSA genotype was first reported in Brazil in 2014, in Feira de Santana, Bahia, in the Northeast region and, in the following years, spread to other states, being identified in Bahia (2014-2017) [9,48,49], Alagoas (2016) [46,50], Piauí (2016-2017) [51], Sergipe (2016) [38], and Maranhão (2017) [40]. It was also identified in the Southeast region, in Rio de Janeiro $(2016-2018)[52,53]$ and Minas Gerais (2017) [54]. Moreover, it has been suggested that the probable introduction of the ECSA genotype in the North occurred from the Northeast in mid-2015 [55]. However, the circulation of the ECSA genotype in the North may be troublesome, as the Asian genotype already circulated in the region since its first introduction in the country, in Oiapoque, Amapá [9]. Surprisingly, their co-infection has already been reported in a recent study in human individuals naturally infected in the Northeast region [55]. It has been shown that both the Asian and ECSA genotypes could spread and co-circulate in the country, considering the vector species suitability [9].

Despite the reports indicating that the introduction of the ECSA genotype was in Brazil in 2014, a recent study showed that this genotype has been circulating in Brazil since 2013, almost a year before it was detected in humans [56]. This highlights the role of entomological surveillance, as the virus may be circulating silently, before human infections may be detected. Furthermore, in recent years, entomo-virological surveillance has proven to be a useful tool for detecting viruses of medical importance during outbreaks, monitoring virus circulation and characterizing vectors, which are crucial in understanding the dynamics of viral transmission.

In this study, the entomological surveillance complemented the clinical observation on the occurrence of chikungunya in Xinguara, Pará, and presented data that reinforce the need and 
importance of vector competence studies in different species of mosquitoes. The vector and virological data, associated with human diagnosis, are imperative to establish strategies for the disease control.

Author Contributions: A.C.R.C., C.F.A. and J.P.N.N., conceptualization; A.C.R.C., C.F.A. and S.P.d.S., data curation; C.F.A. and S.P.d.S., formal analysis; A.C.R.C. and L.C.M., funding acquisition; E.V.P.d.S., J.P.N.N., G.J.G.P., M.M.S., H.A.d.O.M. and S.P.d.S., investigation; J.P.N.N., H.A.d.O.M., C.F.A., S.P.d.S. and A.C.R.C., methodology; A.C.R.C., J.P.N.N. and L.C.M.; project administration; J.P.N.N., E.V.P.d.S., L.C.M. and A.C.R.C., resources; A.C.R.C., supervision; R.J.d.P.S.eG., visualization; F.B.d.S., C.F.A. and A.C.R.C., writing-original draft; C.F.A., A.C.R.C., F.B.S. and L.C.M., Writing-review and editing. All authors have read and agreed to the published version of the manuscript.

Funding: Instituto Evandro Chagas/Ministério da Saúde and to Conselho Nacional de Desenvolvimento Científico e Tecnológico (CNPq) grant number 302462/2018-0 to F.B.S.

Acknowledgments: To the staff of the Seção de Arbovirologia e Febres Hemorrágicas of Instituto Evandro Chagas (SAARB/IEC/SVS/MS) for their support during collection, identification, and analysis of the material. To Secretaria de Saúde do Estado do Pará. To Secretaria Municipal de Saúde de Xinguara, Pará for logistical support. To Red de Laboratorios Entomo-Virologia de Las Americas-PAHO for collaboration in the implementation of the entomo virological network.

Conflicts of Interest: The authors declare no conflict of interest. The funders had no role in the design of the study; in the collection, analyses, or interpretation of data; in the writing of the manuscript, or in the decision to publish the results.

\section{References}

1. Griffin, D.E. Alphaviruses. In Fields Virology; Knipe, D.M., Howley, P.M., Eds.; Lippincott Williams \& Wilkins: Philadelphia, PA, USA, 2013; Volume 1, pp. 651-686.

2. Zeller, H.; Van Bortel, W.; Sudre, B. Chikungunya: Its history in Africa and Asia and its spread to new regions in 2013-2014. J. Infect. Dis. 2016, 214, S436-S440. [CrossRef]

3. Pan American Health Organization Factsheet Chikungunya. Available online: https://www.paho.org/hq/ index.php?option=com_content\&view=article\&id=8303:2013-hoja-informativa-chikungunya\&Itemid= 40023\&lang=en (accessed on 16 May 2020).

4. Cleton, N.B.; Reusken, C.B.; van Gorp, E.C. De chikungunya-epidemie in de Cariben. Ned. Tijdschr. Geneeskd. 2014, 158, A7918. [PubMed]

5. Brasil, Ministério da Saúde and Secretaria de Vigilância em Saúde. Monitoramento dos casos de dengue até a Semana Epidemiológica (SE) 37 e febre de chikungunya até a SE 38 de 2014. Bol. Epidemiol. 2014, 45, 1-6.

6. Brasil, Ministério da Saúde and Secretaria de Vigilância e Saúde. Monitoramento dos casos de dengue, febre de chikungunya e febre pelo vírus Zika até a Semana Epidemiológica 52, 2016. Bol. Epidemiol. 2017, 48, 1-9.

7. Brasil, Ministério da Saúde and Secretaria de Vigilância em Saúde. Monitoramento dos casos de dengue, febre de chikungunya e febre pelo vírus Zika até a Semana Epidemiológica 52, 2017. Bol. Epidemiol. 2018, 49, $1-13$.

8. Wahid, B.; Ali, A.; Rafique, S.; Idrees, M. Global expansion of chikungunya virus: Mapping the 64-year history. Int. J. Infect. Dis. 2017, 58, 69-76. [CrossRef] [PubMed]

9. Nunes, M.R.T.; Faria, N.R.; De Vasconcelos, J.M.; Golding, N.; Kraemer, M.U.G.; De Oliveira, L.F.; Azevedo, R.S.; Da Silva, D.E.A.; Silva, E.V.; Da Silva, S.P.; et al. Emergence and potential for spread of Chikungunya virus in Brazil. BMC Med. 2015, 13, 1-11. [CrossRef]

10. Kotsakiozi, P.; Gloria-Soria, A.; Caccone, A.; Evans, B.; Schama, R.; Martins, A.J.; Powell, J.R. Tracking the return of Aedes aegypti to Brazil, the major vector of the dengue, Chikungunya and Zika viruses. PLoS Negl. Trop. Dis. 2017, 11, e0005653. [CrossRef]

11. Kraemer, M.U.; Sinka, M.E.; Duda, K.A.; Mylne, A.Q.; Shearer, F.M.; Barker, C.M.; Moore, C.G.; Carvalho, R.G.; Coelho, G.E.; Van Bortel, W.; et al. The global distribution of the arbovirus vectors Aedes aegypti and Ae. albopictus. eLife 2015, 4, e08347. [CrossRef]

12. Lima-Camara, T.N. Emerging arboviruses and public health challenges in Brazil. Rev. Saude Publica 2016, 50, 36. [CrossRef]

13. Reinhold, J.M.; Lazzari, C.R.; Lahondère, C. Effects of the environmental temperature on Aedes aegypti and Aedes albopictus mosquitoes: A review. Insects 2018, 9, 158. [CrossRef] [PubMed] 
14. Diallo, M.; Dia, I.; Diallo, D.; Diagne, C.T.; Ba, Y.; Yactayo, S. Perspectives and challenges in entomological risk assessment and vector control of Chikungunya. J. Infect. Dis. 2016, 214, S459-S465. [CrossRef] [PubMed]

15. Lowy, I. Leaking containers: Success and failure in controlling the mosquito Aedes aegypti in Brazil. Am. J. Public Health 2017, 107, 517-524. [CrossRef]

16. Instituto Brasileiro de Geografia e Estatística. Xinguara. Available online: https://cidades.ibge.gov.br/brasil/ pa/xinguara/panorama (accessed on 16 May 2020).

17. Prefeitura Municipal de Xinguara Sobre Xinguara: Clima e Vegetação. Available online: https://www. xinguara.pa.gov.br/ (accessed on 16 May 2020).

18. Lane, J. Neotropical Culicidae; Edusp: São Paulo, SP, Brasil, 1953; Volume 1.

19. Lane, J. Neotropical Culicidae; Edusp: São Paulo, SP, Brasil, 1953; Volume 2.

20. Forattini, O.P. Entomologia Médica. Parte Geral, Diptera, Anophelini; Faculdade de Higiene e Saúde Pública: São Paulo, SP, Brasil, 1962; Volume 1.

21. Forattini, O.P. Entomologia Médica. Culicini: Culex, Aedes e Psorophora; Editora da Universidade de São Paulo: São Paulo, SP, Brasil, 1965; Volume 2.

22. Forattini, O.P. Entomologia Médica. Culicini: Haemagogus, Mansonia, Culiseta, Sabethini, Toxorhynchitini, Arboviroses, Filariose Bancroftiana, Genética; Editora da Universidade de São Paulo: São Paulo, SP, Brasil, 1965; Volume 3.

23. Forattini, O.P. Culicidologia Médica; Universidade de São Paulo: São Paulo, SP, Brasil, 2002; Volume 2, ISBN 85-314-0699-4.

24. Consoli, R.A.G.B.; Lourenço-de-Oliveira, R. Principais Mosquitos de Importância Sanitária no Brasil; Editora Fiocruz: Rio de Janeiro, RJ, Brasil, 1994; ISBN 85-85676-03-5.

25. Tesh, R.B. A method for the isolation and identification of dengue viruses, using mosquito cell cultures. Am. J. Trop. Med. Hyg. 1979, 28, 1053-1059. [CrossRef] [PubMed]

26. Beaty, B.J.; Calisher, C.H.; Shope, R.E. Arboviruses. In Diagnostic Procedures for Viral Rickettsial and Chlamydial Infections; Lennette, E.H., Lunette, D.A., Lenette, E.T., Eds.; American Public Health Association: Washington, DC, USA, 1995; pp. 189-212.

27. Gubler, D.J.; Kuno, G.; Sather, G.E.; Velez, M.; Oliver, A. mosquito cell cultures and specific monoclonal antibodies in surveillance for dengue viruses. Am. J. Trop. Med. Hyg. 1984, 33, 158-165. [CrossRef] [PubMed]

28. Menting, S.; Thai, K.T.D.; Nga, T.T.T.; Phuong, H.L.; Klatser, P.; Wolthers, K.C.; Binh, T.Q.; de Vries, P.J.; Beld, M. Internally controlled, generic real-time PCR for quantification and multiplex real-time PCR with serotype-specific probes for serotyping of dengue virus infections. Adv. Virol. 2011, 2011, 1-9. [CrossRef] [PubMed]

29. Lanciotti, R.S.; Kosoy, O.L.; Laven, J.J.; Panella, A.J.; Velez, J.O.; Lambert, A.J.; Campbell, G.L. Chikungunya virus in US travelers returning from India, 2006. Emerg. Infect. Dis. 2007, 13, 764-767. [CrossRef]

30. Peng, Y.; Leung, H.C.M.; Yiu, S.M.; Chin, F.Y.L. IDBA-UD: A de novo assembler for single-cell and metagenomic sequencing data with highly uneven depth. Bioinformatics 2012, 28, 1420-1428. [CrossRef]

31. Buchfink, B.; Xie, C.; Huson, D.H. Fast and sensitive protein alignment using DIAMOND. Nat. Methods 2015, 12, 59-60. [CrossRef]

32. Huson, D.H.; Auch, A.F.; Qi, J.; Schuster, S.C. MEGAN analysis of metagenomic data. Genome Res. 2007, 17, 377-386. [CrossRef]

33. Katoh, K.; Standley, D.M. MAFFT multiple sequence alignment software version 7: Improvements in performance and usability. Mol. Biol. Evol. 2013, 30, 772-780. [CrossRef]

34. Abascal, F.; Zardoya, R.; Posada, D. ProtTest: Selection of best-fit models of protein evolution. Bioinformatics 2005, 21, 2104-2105. [CrossRef]

35. Myung, I.J. Tutorial on maximum likelihood estimation. J. Math. Psychol. 2003, 47, 90-100. [CrossRef]

36. Stamatakis, A. RAxML version 8: A tool for phylogenetic analysis and post-analysis of large phylogenies. Bioinformatics 2014, 30, 1312-1313. [CrossRef]

37. Felsenstein, J. Confidence limits on phylogenies: An approach using the bootstrap. Evolution 1985, 39, 783-791. [CrossRef] [PubMed]

38. Costa-da-Silva, A.L.; Ioshino, R.S.; Petersen, V.; Lima, A.F.; Cunha, M.d.P.; Wiley, M.R.; Ladner, J.T.; Prieto, K.; Palacios, G.; Costa, D.D.; et al. First report of naturally infected Aedes aegypti with chikungunya virus genotype ECSA in the Americas. PLoS Negl. Trop. Dis. 2017, 11, e0005630. [CrossRef] 
39. Aragão, C.F.; Cruz, A.C.R.; Neto, J.P.N.; de Oliveira Monteiro, H.A.; da Silva, E.V.P.; da Silva, S.P.; Andrade, A.T.d.S.; Tadei, W.P.; Pinheiro, V.C.S. Circulation of Chikungunya virus in Aedes aegypti in Maranhão, Northeast Brazil. Acta Trop. 2018, 186, 1-4.

40. Aragão, C.F.; Pinheiro, V.C.S.; Nunes-Neto, J.P.; Silva, E.V.P.; Pereira, G.J.G.; Nascimento, B.L.S.; Castro, K.D.S.; Maia, A.M.; Catete, C.P.; Martins, L.C.; et al. Natural infection of Aedes aegypti by Chikungunya and Dengue type 2 virus in a transition area of North-Northeast Brazil. Viruses 2019, 11, 1126. [CrossRef] [PubMed]

41. de Melo-Ximenes, M.d.F.F.; Galvão, J.M.d.A.; Inacio, C.L.S.; Macêdo-e-Silva, V.P.; Pereira, R.L.d.N.; Pinheiro, M.P.G.; Siva, M.M.d.M.; Gomes, C.E.S. Arbovirus expansion: New species of culicids infected by the Chikungunya virus in an urban park of Brazil. Acta Trop. 2020, 209, 105538. [CrossRef]

42. Ponce-García, G.; Flores-Suarez, A.E.; Villanueva-Segura, K.; Lopez-Rodriguez, M.; Dzul, F.; Lopez-Monroy, B.; Rodriguez-Sanchez, I. Report of Chikungunya virus in wild populations of Aedes aegypti in Guerrero State, Mexico. J. Am. Mosq. Control Assoc. 2018, 34, 147-150. [CrossRef]

43. Intayot, P.; Phumee, A.; Boonserm, R.; Sor-suwan, S.; Buathong, R.; Wacharapluesadee, S.; Brownell, N.; Poovorawan, Y.; Siriyasatien, P. Genetic characterization of Chikungunya virus in field-caught Aedes aegypti mosquitoes collected during the recent outbreaks in 2019, Thailand. Pathogens 2019, 8, 121. [CrossRef] [PubMed]

44. Vega-Rua, A.; Zouache, K.; Girod, R.; Failloux, A.-B.; Lourenco-de-Oliveira, R. High level of vector competence of Aedes aegypti and Aedes albopictus from ten American countries as a crucial factor in the spread of Chikungunya virus. J. Virol. 2014, 88, 6294-6306. [CrossRef] [PubMed]

45. Sardi, S.I.; Somasekar, S.; Naccache, S.N.; Bandeira, A.C.; Tauro, L.B.; Campos, G.S.; Chiu, C.Y. Coinfections of zika and Chikungunya viruses in bahia, Brazil, identified by metagenomic next-generation sequencing. J. Clin. Microbiol. 2016, 54, 2348-2353. [CrossRef]

46. Da Costa, A.C.; Thézé, J.; Komninakis, S.C.V.; Sanz-Duro, R.L.; Felinto, M.R.L.; Moura, L.C.C.; Barroso, I.M.d.O.; Santos, L.E.C.; Nunes, M.A.d.L.; Moura, A.A.; et al. Spread of Chikungunya virus East/Central/South African genotype in Northeast Brazil. Emerg. Infect. Dis. 2017, 23, 1742-1744. [CrossRef]

47. Naveca, F.G.; Claro, I.; Giovanetti, M.; De Jesus, J.G.; Xavier, J.; Iani, F.C.d.M.; Nascimento, V.A.; Souza, V.C.; Silveira, P.P.; Lourenço, J.; et al. Genomic, epidemiological and digital surveillance of Chikungunya virus in the Brazilian Amazon. PLoS Negl. Trop. Dis. 2019, 13, e0007065. [CrossRef] [PubMed]

48. Tauro, L.B.; Cardoso, C.W.; Souza, R.L.; Nascimento, L.C.J.; Santos, D.R.; Campos, G.S.; Sardi, S.; Reis, O.B.; Reis, M.G.; Kitron, U.; et al. A localized outbreak of Chikungunya virus in Salvador, Bahia, Brazil. Mem. Inst. Oswaldo Cruz 2019, 114, e180597. [CrossRef] [PubMed]

49. de-Jesus, J.G.; da Luz Wallau, G.; Lima-Maia, M.; Xavier, J.; Oliveira Lima, M.A.; Fonseca, V.; de Abreu, A.S.; Tosta, S.F.O.; Do Amaral, H.R.; Lima, I.A.B.; et al. Persistence of Chikungunya ECSA genotype and local outbreak in an upper medium class neighborhood in Northeast Brazil. PLoS ONE 2020, 15, e0226098.

50. Tanabe, E.L.d.L.; Tanabe, I.S.B.; Santos, E.C.d.; Marques, J.P.d.S.; Borges, A.A.; Lima, M.C.d.; Anderson, L.; Bassi, E.J. Report of East-Central South African Chikungunya virus genotype during the 2016 outbreak in the Alagoas State, Brazil. Rev. Inst. Med. Trop. Sao Paulo 2018, 60, e19. [CrossRef]

51. Cardoso, F.D.; Rezende, I.M.d.R.; Barros, E.L.T.; Sacchetto, L.; Garcês, T.C.d.C.S.; Silva, N.I.O.; Alves, P.A.; Soares, J.O.; Kroon, E.G.; Pereira, A.C.T.d.C.; et al. Circulation of Chikungunya virus East-Central-South Africa genotype during an outbreak in 2016-17 in Piaui State, Northeast Brazil. Rev. Inst. Med. Trop. Sao Paulo 2019, 61, e57. [CrossRef]

52. Souza, T.M.A.; Azeredo, E.L.; Badolato-Corrêa, J.; Damasco, P.V.; Santos, C.; Petitinga-Paiva, F.; Nunes, P.C.G.; Barbosa, L.S.; Cipitelli, M.C.; Chouin-Carneiro, T.; et al. First report of the East-Central South African genotype of Chikungunya virus in Rio de Janeiro, Brazil. PLoS Curr. 2017, 9. [CrossRef]

53. Xavier, J.; Giovanetti, M.; Fonseca, V.; Thézé, J.; Gräf, T.; Fabri, A.; de Jesus, J.G.; de Mendonça, M.C.L.; dos Santos Rodrigues, C.D.; Mares-Guia, M.A.; et al. Circulation of Chikungunya virus East/Central/South African lineage in Rio de Janeiro, Brazil. PLoS ONE 2019, 14, e0217871. [CrossRef] [PubMed]

54. Lessa-Aquino, C.; Trinta, K.S.; Pestana, C.P.; Ribeiro, M.O.; Sucupira, M.V.F.; Boia, M.N.; Baptista, P.A.; Cunha, R.V.; Medeiros, M.A. Detection of East/Central/South African genotype Chikungunya virus during an outbreak in a southeastern state of Brazil. Epidemiol. Infect. 2018, 146, 2056-2058. [CrossRef] [PubMed] 
55. Machado, L.C.; de Morais-Sobral, M.C.; Campos, T.d.L.; Pereira, M.R.; de Albuquerque, M.d.F.P.M.; Gilbert, C.; Franca, R.F.O.; Wallau, G.L. Genome sequencing reveals coinfection by multiple Chikungunya virus genotypes in a recent outbreak in Brazil. PLoS Negl. Trop. Dis. 2019, 13, e0007332. [CrossRef] [PubMed]

56. Souza, T.M.L.; Vieira, Y.R.; Delatorre, E.; Barbosa-Lima, G.; Luiz, R.L.F.; Vizzoni, A.; Jain, K.; Miranda, M.M.; Bhuva, N.; Gogarten, J.F.; et al. Emergence of the East-Central-South-African genotype of Chikungunya virus in Brazil and the city of Rio de Janeiro may have occurred years before surveillance detection. Sci. Rep. 2019, 9, 2760. [CrossRef]

(C) 2020 by the authors. Licensee MDPI, Basel, Switzerland. This article is an open access article distributed under the terms and conditions of the Creative Commons Attribution (CC BY) license (http://creativecommons.org/licenses/by/4.0/). 